\author{
Halina Wiśniewska \\ Uniwersytet Marii Curie-Skłodowskiej w Lublinie
}

DOI $10.19195 / 1642-5782.15(25) .2$

\title{
Uczniowskie zabawy nazwami dźwięków w polskim języku
}

Wiadomo, że można mówić tak, by słuchacza rozśmieszyć żartem czy dowcipem. Do znanych przed wiekami „rozśmiewaczy” należy wielu wierszopisów, nawet wybitni poeci nie pogardzali układaniem błazeństw chętnie czytanych, ale mniej cenionych przez intelektualistów. Tworzyli je na przykład Biernat z Lublina (druga połowa XV w.-po 1529), Mikołaj Rej z Nagłowic (1505-1569), Ignacy Krasicki (1735-1801) z Dubiecka, Julian Tuwim (1894-1953)1. Gdy czytamy rymowane fraszki i bajki, do dzisiaj zadziwiają nas one figlowaniem oraz żartowaniem ${ }^{2}$. Zaskakują niespodziewanym zestawem wyrazów i zwrotów, prześmiesznym brzmieniem wypowiedzi, oryginalnym spojrzeniem na rzeczywistość. Nic dziwnego, że nie pomijamy kształcenia tej umiejętności (dowcip, figiel, psikus, żart) w dydaktyce języka polskiego ${ }^{3}$. Wiedzę o dowcipie językowym ${ }^{4}$ wprowadzamy do poradników i podręczników, dajemy nauczycielom przykłady lekcji na ten temat ${ }^{5}$.

W niniejszym artykule eksponuję szczególnie wyrazy dźwiękonaśladowcze, które odbieramy zmysłem słuchu ${ }^{6}$, a także przypominam miłe dla uszu rymowan-

${ }^{1}$ Biernat z Lublina, Ezop, Kraków, ok. 1520; Mikołaj Rej z Nagłowic, Figliki, Kraków 1562; I. Krasicki, Bajki i przypowieści, Warszawa 1779; J. Tuwim, Cztery wieki fraszki polskiej, Warszawa 1937.

${ }^{2}$ Wyrazy pisane kursywą są hasłami w: G. Knapiusz, Thesaurus polono-latino-graecus, wyd. 2, Kraków 1643, s.v.

${ }^{3}$ H. Wiśniewska, Nauczanie dowcipu w szkole, [w:] Humor i karnawalizacja we współczesnej komunikacji językowej, red. J. Mazur, M. Rumińska, Lublin 2007, s. 113-122.

${ }^{4}$ D. Buttler, Polski dowcip językowy, Warszawa 1974; Humor w perspektywie kulturowo-językowej, red. M. Karwatowska, L. Tymiakin, Lublin 2013, s. 260.

${ }^{5}$ W. Gawdzik, Gramatyka na wesoło, Warszawa 1970; idem, Ortografia na wesoło, Warszawa 1971; M. Jędrychowska, Poza nuda. O zabawach, grach i rozrywkach, „Ojczyzna-Polszczyzna” 1992, nr 4; Gry i zabawy w ksztatceniu językowym. Propozycje - scenariusze - projekty, red. H. Wiśniewska, Lublin 2000, s. 206 (tu bibliografia).

${ }^{6}$ Praktyczny słownik wspótczesnej polszczyzny, red. H. Zgółkowa, Poznań 1994-2005, s. V. 
ki, powtórzenia, tak zwane łamańce słowne itp. Przyzwyczajeni do hałasu (szczególnie w miastach), nie zawsze zwracamy uwagę na to, co słyszymy z przestrzeni. Tymczasem warto także pamiętać, że powstają wówczas dźwięki różnego rodzaju, artykułowane przez ludzi, wydawane przez urządzenia techniczne, elektryczne, zwierzęta, naturę 'przyroda', jakie krótko opisuje się w gramatyce, a wykorzystuje w codziennym mówieniu, czasem też w utworach poetyckich.

Zaprezentuję znane dźwięki, przedstawiając krótko i zwięźle możliwości komunikacyjne na lekcjach, ukazując ich walory w dowcipach i śmiesznych wypowiedziach. Chodzi o to, by przypomnieć nauczycielom tworzywo językowe, jakim jest dźwięk, i ułatwić zorganizowanie lekcji poświęconej na naukę słyszenia tego, co wokół nas tłucze się i brzęczy. Cenimy bardzo tych polonistów, którzy potrafią nauczyć odbiorców pośmiania się trochę z rezultatów swoich ćwiczeñ ${ }^{7} \mathrm{i}$ uznania, że Śmiech to zdrowie, Więcej zrobisz śmiechem, niż wyrąbiesz mieczem ${ }^{8}$.

\section{A. Analiza gramatyczna. Części mowy}

Okazuje się, że tylko trzy części mowy informują o hałasach i odgłosach naszego otoczenia. Funkcje te spełniają niektóre rzeczowniki, czasowniki, a przede wszystkim wykrzykniki oraz wykrzyknienia.

\section{Rzeczowniki (onomatopeje)}

Zaledwie kilkadziesiąt rzeczowników to wyrazy naśladujące dźwięki i odgłosy pozajęzykowe, które podzieliłam na kilka grup.

a) Charakterystyczna cecha pierwszej grupy to krótkość wyrazu (jedna, czasem dwie sylaby) oraz obecność spółgłosek $(k, r, s, t ; c z, s z, r z)$, które szybko wpadają w uszy: dźwięk, głos, grom, gwar, huk, klask, krzyk, kwak, odgłos, pisk, płacz, rum, ryk, skok, skowyt, spór, swar, szelest, szept, szmer, szum, śmiech, trzask, wrzask, zgiełk, żart. Wszystkie cytowane wyrazy zanotował już przed wiekami w słowniku Grzegorz Knapiusz (dalej: Cn) ${ }^{9}$.

b) W grupie drugiej wyodrębniam dwusylabowce z tym samym zakończeniem -ot: blekot, chrobot, furkot, gruchot (Cn), grzechot, grzmot (Cn), hurkot, jazgot, klekot, tomot (Cn), topot, toskot (Cn), mamrot, rzekot, stukot, stupot, szczebiot (Cn), szurgot, świegot (Cn), świergot, terkot, trajkot, trzepot, tupot. Wyrazy te informują o zachowaniu się osób, zwierząt, ale i przedmiotów; część wyrazów była znana Knapiuszowi.

${ }^{7}$ R. Pawłowska, Praca nad znaczeniem wyrazu na lekcjach języka polskiego, „Kształcenie Językowe w Szkole" 10, 1998, s. 103-119.

${ }^{8}$ Praktyczny stownik współczesnej polszczyzny, t. 42, s. 90.

${ }^{9}$ G. Knapiusz, op. cit., s. 1488. 
c) Najwięcej mamy rzeczowników odczasownikowych z formantem -aniel -enie, również zanotowanych przez Knapiusza w XVII wieku, np.: betkotanie 'niewyraźna mowa', brząkanie 'dźwięk struny', dmuchanie 'silne wianie', gdakanie 'powtarzające się dźwięki, np. 'kury', gęganie 'głos gęsi', grzechotanie 'przerywany dźwięk', grzmienie 'potężny huk', klaskanie 'odgłos uderzania dłonią w dłoń', kopanie 'osiem znaczeń, np. silne uderzenie nogą', plaskanie 'dźwięk podczas uderzenia jednej płaszczyzny w inną', pukanie 'dobijanie się, stukanie', sarkanie 'wyrażanie irytacji', skrzeczenie 'dźwięk np. żab', trąbienie 'gra na dętym blaszanym instrumencie', żartowanie 'gra słów, sytuacje, które mają kogoś doprowadzić do śmiechu' ${ }^{10}$.

d) Śmieszą i bawią nas wyrazy dźwiękonaśladowcze rymowane: abrakadabra 'zaklęcie magiczne', czary-mary 'zaklęcie', esy-floresy 'zawiłe rysunki', figle-migle 'psikusy', hokus-pokus 'zaklęcie', fikołki-koziołki 'gimnastyczna zabawa', szuru-buru 'zamęt', tere-fere (Cn) 'krętactwo', trele-morele 'brednie, zmyślenia'.

Zgromadzone tu przykłady rzeczowników znane były w większości Polakom już od stuleci. Stanisław Jodłowski włączył je do ,kategorii epistemologicznych rzeczownych", podkreślając ich derywację odrzeczownikową; Roman Laskowski zwrócił uwagę na odrzeczownikową i odsłowną derywację, ale także na to, że charakteryzuje je dźwiękonaśladownictwo, szczególnie przyrody, „odzwierciedlenie dźwięków pozajęzykowych" oraz nietypowe połączenia fonemów (r, 1, ś, ć) ${ }^{11}$.

Wypada dodać, że te wyrazy mają dzisiaj liczne synonimy, niektóre zadziwiają nas wielkością pola synonimów (od 2 do 24 haseł $)^{12}$ :

huk (24): łoskot, łomot, hałas, grzmot, trzask, huknięcie, grzmotnięcie, grom, trzaśnięcie, prask, hurgot, hurkot, turgot, warkot, grzechot, gruchot, klekot, chrobot, chrupot, tupot, brzdęk, ryk, wrzask, krzyk;

odglos (17): dźwięk, szelest, pomruk, poszept, poszum, pogwar, poświst, pohukiwanie, poświstywanie, pogwizdywanie, pojękiwanie, pomrukiwanie, popiskiwanie, pochlipywanie, postękiwanie, szczebiotanie, wzdychanie;

trzask (17): huk, huknięcie, grzmotnięcie, grzmot, grom, piorun, trzaśnięcie, prask, łomot, łoskot, rumor, zgrzyt, zgrzytnięcie, skrzyp, skrzypnięcie, skrzypienie, hatas;

trele morele (15): bzdury, niedorzeczności, brednie, androny, głupstwa, dyrdymaty, banialuki, pierdoły, duperele, bzdety, głodne kawałki, farmazony, duby smalone, koszałki-opatki, klituś-bajduś;

gwar (12): hałas, zgiełk, tumult, zamieszanie, wrzawa, rwetes, ruch, raban, rejwach, harmider, gwatt, rozgwar.

Barbara Boniecka dowiodła w szczegółowych badaniach, że rzeczowniki onomatopeiczne pełnią różne funkcje składniowe:

10 Objaśnienia za: Praktyczny słownik współczesnej polszczyzny.

11 S. Jodłowski, Podstawy polskiej składni, Warszawa 1976, s. 22; R. Laskowski, Wykrzykniki, [w:] Encyklopedia języka polskiego, red. S. Urbańczyk, M. Kucała, Wrocław 1999, s.v.

12 Praktyczny słownik wspótczesnej polszczyzny. 
podmioty są dość rzadkie, przydawki mogą być traktowane jako atrybuty, a semantycznie pełnią funkcje predykatów, dopełnienia biernikowe są najczęstsze, okoliczniki to najswobodniejsze składniki zdania. Wyrazy onomatopeiczne występują też w przytoczeniach oraz w wyrazach-zdaniach ${ }^{13}$.

Niewiele rzeczowników ma swoje uzupełnienie w wyrazach nazywających działanie, czyli czynności.

\section{Czasowniki (onomatopeje)}

Zdecydowanie więcej używano (i używa się) czasowników nazywających dźwięki i ruchy, informujące o porozumiewaniu się osób:

- głosem, ale nie słowami, np. bełkotać, chichotać, fukać, krzyczeć, mamrotać, sapać, sarkać, szemrać, śmiać się;

- mimiką twarzy, np. krzywić się, migać, mrugać, pokazywać język, przedrzeźniać kogoś, przytakiwać, puszczać oczko, robić dziwne miny, rozśmieszać kogoś, śmiać się, uśmiechać się, zaprzeczać;

- gestami, ruchem rąk, np. bić kogoś lub brawa, klaskać, klasnać, klepać, kołatać, łomotać, pluskać, pchać, pukać, skrobać, szarpać, trząść, trzepać, uderzać; tupać.

— ruchami nóg, np. biegać, chodzić, deptać, kopać kogoś, skakać, tańczyć,

Wydawanie głosu dotyczy też zwierząt, w tym szczególnie ptaków, np. beknać, brzmieć, ćwierkać, gdakać, gegać, gruchać, kwilić, krakać, kukać, mruczeć, muczé́, piskać, piszczé́, ryczé́, rzegocić, syczé́, szczebiotać, szczekać, szczerzyć (zęby), świegotać, trąbić, trzepotać, warczé́, wyć, zgrzytać (zębami) ${ }^{14}$.

Językoznawcy dostrzegają szeroki zakres wyobrażen wywotywanych przez te wyrazy, które stanowią podstawę derywatów czasowników postwerbalnych (zero formantowe, czyli derywacja wsteczna). S. Jodłowski nazwał je czasownikami niefleksyjnymi, nieosobowymi, Stanisław Rospond zwrócił uwagę, że pełnią funkcje impresywne (np. precz, fora, hajda, huzia, wara) lub ukazują czynności momentalne (np. bęc, bzdęk, ciach) ${ }^{15}$. Wyrazy naśladowcze uznaje B. Boniecka między innymi za wykrzykniki, amorficzne czasowniki:

Rozpatrywanie ich właśnie z pozycji wyrazów-obrazów, tworów o dużym realizmie językowym, globalnych znaków treści (ich peryferyczne miejsce w zasobach języka wydaje się tu mało istotne), wyrazów znaczących już przez samą odmienną naturę, tworów o dużym ładunku ekspresywno-impresywnym pozwala na wyznaczenie ich miejsca w układach składniowych, czyli na określenie ich wartości syntaktycznej ${ }^{16}$.

${ }_{13}$ B. Boniecka, Funkcje sktadniowe wyrazów onomatopeicznych, „Polonika” 1977, z. 3, s. $33-41$.

${ }^{14}$ M. Mączyński, O czasownikach onomatopeicznych oznaczających mówienie, „Język Polski" 1984, z. 1-2; s. 105.

15 S. Jodłowski, Polskie czasowniki niefleksyjne, [w:] W stużbie nauce i szkole, red. M. Szymczak, Warszawa 1970, s. 131-136; S. Rospond, Gramatyka historyczna języka polskiego, Warszawa 1971, s. 200.

${ }^{16}$ B. Boniecka, op. cit., s. 28-29 (tu bibliografia). 


\section{Wykrzykniki (onomatopeje)}

Uwagę badaczy (i poetów) zwracają szczególnie wykrzykniki ${ }^{17}$, którym przypisuje się wyrażanie uczuć i woli. W gramatyce współczesnego języka polskiego o wykrzyknikach pisze się tak:

Leksemy asyntagmatyczne funkcjonują prymarnie jako samodzielne wypowiedzenia, nie wchodząc w związki syntaktyczne z innymi elementami tekstu; są to wyrażenia typu: hej!, bęc, halo!, $b z z, t a k$, nie. Leksemy niekontekstualne nie implikują istnienia tekstu, mogą samodzielnie stanowić pełny tekst. Są to wykrzykniki, np. uwaga, psst!, brzęk, mee. Rozpadają się na dwie podklasy: apele i onomatopeje. Pierwsze mogą sekundarnie łączyć się z formami trybu rozkazującego (Halo, poczekajcie!). Drugie sekundarne występują w funkcji członu głównego wyrażenia zdaniowego w typie: Dziecko bęc jak dtugie, Kula tylko bzz koło ucha ${ }^{18}$.

\section{Z kolei w jednym ze słowników:}

Wykrzyknik. 2. Nieodmienna część mowy, pozbawiona treści pojęciowej, służąca do wyrażania stanów uczuciowych, przejawów woli lub do naśladowania odgłosów różnych zjawisk i istot, nie wchodząca w związki syntaktyczne z innymi wyrazami ${ }^{19}$.

Zauważono, że wykrzyknikami się naśladuje głosy instrumentów i zwierząt, odgłosy czynności ludzi, fauny i maszyn. Dane pozwalają nam podzielić formalnie wykrzykniki na jednosylabowe samogłoskowe i spółgłoskowe.

a) Okazuje się, że większość samogłosek polskich spełnia znaczeniowo funkcję emocjonalną i wolicjonalną, wyrażając różne przeżywane stany, dotyczące wypowiedzi człowieka ${ }^{20}$ : a, aaa 'zaskoczenie, zdziwienie, ulga, rozleniwienie'; ach, ach 'radość, zachwyt, uwielbienie'; e, eee, ech 'powątpiewanie, zniecierpliwienie, zniechęcenie'; ej, ejże 'ostrzeżenie, przestroga, przywoływanie kogoś'; och 'zdumienie, zaskoczenie, zagrożenie, podziw'; oj 'zaskoczenie, poczucie bólu, zagrożenie'; $u$, jak boli! 'zaskoczenie'.

b) Część wykrzykników spółgłoskowych jest jednosylabowa, ale ich wykonawcy są zróżnicowani (osoba, fauna, maszyna): be, fe, fuj 'dezaprobata'; buch 'uderzenie pary lub powietrza'; chlap, chlup 'ruch wody'; dzyń, dzyn' 'dzwonki', fitu, fitu 'dźwięki smyczkowe'; fiu, fiu 'zdumienie, podziw'; ha, ho, ho, ho 'podziw, uznanie, czasem groźba'; $h u, h u, h u$ 'podziw, wesołość, zdziwienie; klask, plask 'odgłos uderzenia rękami'; kwa, kwak 'głos kaczki'; pfe, pfu, pfuj 'obrzydzenie, odraza, niesmak'; phi 'pogarda, lekceważenie, niechęć'; prr 'rozkaz skierowany do konia, by się zatrzymał'; puk, puk 'stukanie, kołatanie rękami'; tik-tak

17 S. Jodłowski, Podstawy polskiej składni, s. 22, 210; Z. Klemensiewicz, Składnia, stylistyka, pedagogika językowa, red. A. Kałkowska, Warszawa 1982, s. 114, 131, 489; P. Bąk, Gramatyka języka polskiego, Warszawa 1977, s. 167- 169.

${ }^{18}$ R. Laskowski, Podstawowe pojęcia morfologii, [w:] Gramatyka wspótczesnego języka polskiego. Morfologia, red. R. Grzegorczykowa, R. Laskowski, H. Wróbel, Warszawa 1984, s. 31.

${ }_{19}$ Praktyczny słownik wspótczesnej polszczyzny, s.v.

20 Ibidem; J. Bralczyk, Aaa, kotki dwa, szare, bure obydwa, [w:] Język polski. Arkusze maturalne, red. M. Magenta-Siemiaszko, Warszawa 2016, s. 38. 
'odgłos zegara'; trr 'warkot silnika'; tra ta ta 'gra na trąbce'; tu-tu-tu 'odgłos klaksonu'; tup-tup 'dreptanie'; tuś, tuś 'głosy kaczek'; wio 'rozkaz do konia'; wrr 'pies ostrzega przed napaścią'.

c) Grupę kolejną stanowią jednosylabowce, stosunkowo trudne do odróżnienia od rzeczowników: brzdęk (Cn), chlap, ćwierk, ćwir, ćwierkot, fuk (Cn), halo, hallo, hup (Cn), hurgot, klask, kwa, kwak, kuku, mru-mru, mruk, plask (Cn), plum, skrzyt (Cn), skrzek, skrzyp (Cn), smyk (Cn), tętent, trach 'rozbicie, rozdarcie czegoś'; trzask 'upadek'; tyr, tyr, tyr 'dźwięk samochodu'; wiśta, fiku-miku (Cn) 'ruch'; fiu-bździu (Cn) 'drobiazg'; szuru-buru 'zamęt'.

Zebranie przez uczniów tego słownictwa i uczynienie leksykonów alfabetycznych stanowiłoby dobrą okazję przeżycia interesującej lekcji. Nie zabronimy też uczniom korzystania z gotowych zapisów znajdowanych w Internecie, niemniej różne miejsca i zdarzenia stanowią wystarczające źródła dla zebrania „na żywo” tematycznej leksyki, np. przerwa w szkole, nabożeństwo w kościele, zakupy w dużym sklepie, ,podsłuch” na boisku sportowym i w hali fabrycznej, odgłosy burzy na osiedlu czy we wsi itp.

B. Boniecka wynotowała z utworów literackich 680 haseł, z których aż $21 \%$ to orzeczenia w dominujących ilościowo zdaniach współrzędnych. Stwierdza: „Wyrazy onomatopeiczne już przez to, że momentalne, więc przez swą naturę czynią tekst bardziej swobodnym, stwarzają iluzję kolokwialności wypowiedzi"21.

Onomatopeje (rzeczowniki i czasowniki, także czasowniki niefleksyjne oraz wykrzykniki) wprowadził do swoich bajek już np. Biernat z Lublina (1522), dwukrotnie opisał je G. Knapiusz w Thesarusie ${ }^{22}$, a artykułami zwrócono specjalną uwagę na dźwięki i trele ptaków ${ }^{23}$.

\section{Zwroty frazeologiczne}

Przez frazeologizmy rozumiemy połączenia wyrazowe o względnie stałej strukturze składniowej i autonomii znaczeniowej ${ }^{24}$. Części frazeologizmów używamy niezmiennie od stuleci, ale część się zmieniła, dlatego badacze opisują ich aktualne osobliwości fleksyjne, składniowe, strukturę, normy, innowacje, błędy ${ }^{25}$. Dzisiejsi użytkownicy frazeologizmów chętnie je łączą, zmieniają, skracają itp., ale niekiedy bez rozumienia ich znaczeń, szczególnie tych sprzed wieków, co mimo woli wywołuje śmiech. Frazeologizmy personifikują i antropomorfizują, jak w przedstawionej

${ }^{21}$ B. Boniecka, op. cit., s. 33.

22 J. Puzynina, O metodzie leksykograficznej w „Thesaurusie” Knapskiego, „Poradnik Językowy" 1956, z. 4, s. 121-129, z. 5, s. 168-175; z. 6, s. 216-221.

${ }^{23}$ M. Mączyński, op. cit., s.19; H. Wiśniewska, Zasobność słownika ,verba dicendi” w bajkach Biernata z Lublina, [w:] W kręgu dawnej polszczyzny, red. M. Mączyński, E. Horyń, E. Żmuda, Kraków 2016, s. 135.

${ }^{24}$ Praktyczny słownik wspótczesnej polszczyzny, s.v. Frazeologizm.

25 S. Bąba, Innowacje frazeologiczne współczesnej polszczyzny, Poznań 1989; Statość i zmienność zwiazków frazeologicznych, red. A.M. Lewicki, Lublin 1982. 
grupie przykładów, w których pisano o instytucjach tak jak o człowieku, który myśli, czuje i przeżywa wydarzenia w dzisiejszej rzeczywistości:

Cegielnia nie zawraca sobie głowy trocinami; Handel trzyma rękę na pulsie; Miłość wyszła obronną ręką z niełatwej próby; NATO chowa głowę w piasek; Partia sypie popiół na swoją głowę; Przemysł papierniczy rozkłada rękę; Rząd utarł nosa związkowcom; Warsztaty rzemieślnicze mają być solą w polskiej gospodarce; Zakłady odzieżowe złapały wiatr w żagle ${ }^{26}$.

Niektóre z nich śmieszą, sprawiają wrażenie, że użytkownicy nie dość dokładnie rozumieją znaczenia i nie potrafią poprawnie stosować zwrotów frazeologicznych albo też świadomie przesadzają dla celów perswazyjnych właściwych publicystyce.

Badania ${ }^{27}$ ukazują trudności uczniów w wyjaśnieniu znaczeń dziesięciu frazeologizmów: łacina kuchenna, Janusowe oblicze, łabędzia pieśń, latający Holender, człowiek starej daty, lwia część, dantejskie sceny, osioł dardanelski, robić komuś gębę, mówić jak nakręcony. Najbardziej nieznane wyrażenie to łacina kuchenna; frazeologizm rozumiało należycie tylko ośmiu uczniów, a trzynastu taktownie je pominęło, gdy 79 opisało je błędnie. Trochę lepsze wyniki dotyczyły drugiego ,łacińskiego" wyrażenia: Janusowe oblicze; dziewiętnastu uczniów znało poprawnie frazeologizm, aż 32 osoby w ogóle nie podały znaczenia, a 49 błędnie je wytłumaczyło.

Jedną z przyczyn tego stanu może być nieznajomość łaciny, dawniej nauczanej powszechnie. Wiele frazeologizmów wymaga znajomości historii starożytnej i polskiej od średniowiecza. Z uwagą czytamy objaśnienia zwrotów ${ }^{28}$, które przypominają na przykład nieludzkie karanie w dawnych wiekach: ktoś plecie jak Piekarski na mękach, ktoś ujmuje kogoś w kluby, ktoś drze z kogoś pasy, ktoś zalat komuśs sadta goracego za skórę, ktoś stawia kogoś pod pregierzem i inne. Anna Pajdzińska kończy swoje rozważania uwagą:

Frazeologizmy o niejasnej dla mówiących motywacji łatwiej ulegają różnego rodzaju zmianom semantycznym i formalnym. Ten fragment zasobu leksykalnego pokazuje zatem, jak ściśle są ze sobą związane język i świat członków wspólnoty komunikatywnej, jak zmiany rzeczywistości kulturowej pociągają za sobą zmiany językowe.

Z kolei Helena Synowiec po dokonaniu badań zachęca nauczycieli do poświęcenia więcej czasu znaczeniom frazeologizmów, szczególnie tym dawnym, przywołującym inną kulturę. Proponuje też wykorzystanie „młodzieżowej” odmiany języka, którą można łączyć z kształceniem sprawności komunikacyjnej. Stwierdza, że propozycje ćwiczeń zamieszczone w podręcznikach są niewspółmierne do indywidualnych potrzeb ${ }^{29}$.

${ }^{26}$ S. Bąba, Indeks innowacji frazeologicznych, [w:] idem, Innowacje frazeologiczne wspótczesnej polszczyzny, s. 203-208.

27 A. Mikołajczyk, Rozumienie znaczenia wybranych związów frazeologicznych $w$ testach egzaminacyjnych na polonistyke, „Studia Pragmalingwistyczne” 1997, s. 91-105.

28 A. Pajdzińska, Frazeologia a zmiany kulturowe, [w:] eadem, Studia frazeologiczne, Łask 2006, s. 61-71.

${ }^{29}$ H. Synowiec, Problemy frazeologii w kształceniu językowym uczniów, [w:] Wiedza o języku i kompetencje językowe uczniów, red. B. Niesporek-Szamburska, Katowice 2012, s. 295-296. 


\section{B. Analiza komunikacji tekstowej}

Wyekscerpowane w artykule onomatopeje i frazeologizmy nie wyczerpują materiału i okazji do mówienia i pisania w szkole o humorze słownym. Znajdujemy stosunkowo dużo „rozśmieszających” gatunków w literaturze, np. anegdota, arlekinada, bajka ezopowa, epigramat, dykteryjka, facecja, farsa, figliki, fraszka, groteska, humoreska ${ }^{30}$, obfitujących w dowcip językowy, humor, ironie, komizm, nonsens, parodię. Uczniowie mogą czerpać z nich wzory.

$\mathrm{Na}$ co dzień spotykamy się z dowcipami okolicznościowymi lub powtarzanymi z zapisów w gazetach, tygodnikach, kalendarzach itp. Ponieważ zadaniem nauczycieli jest nauczenie młodzieży dostrzegania śmieszności na co dzień i od święta, przypomnimy kilka rodzajów tekstów „z dźwiękami”, jakie wypada poznać w trakcie nauki w szkole.

\section{Zabawa spółgłoskami w wyrazach (łamańce słowne)}

By bawić się spółgłoskami, warto najpierw przypomnieć uczniom wiadomości o nich, gdyż ich nazwy mówią o specjalnej artykulacji, np. spótgłoska dźwięczna, szczelinowa, zwarta. Można uczniów zachęcić do pisania ${ }^{31}$ różnorodnych śmiesznych tekstów rymowanych, bawiących dźwiękami poszczególnych liter. Oto przykłady, w których honoruje się samogłoski nosowe oraz spółgłoski zwarte i szczelinowe:

Spadt bąk na strąk, a strąk na bąk. Pękt pąk, pękt strąk, a bąk się zląkt.

Za parkanem wśród kur na podwórku kroczyt kruk w purpurowym kapturku, raptem strasznie zakrakat i zrobiła się draka, bo mu kura ukradła robaka.

$W$ trzęsawisku trzeszcza trzciny, trzmiel trze w Trzciance trzy trzmieliny, a trzy byczki znad Trzebyczki z trzaskiem trzepia trzy trzewiczki. Wydaje się, że w każdej klasie warto, by uczniowie zabawili się pisaniem tego rodzaju „słownych łamańców". Może odkryjemy słuchowo utalentowanych uczniów?

\section{Homonimy}

Warto też w klasach zwrócić uwagę na tożsamość brzmieniową wyrazów, czyli zaprezentować homonimy 'znaczące jednostki języka, które charakteryzują się tożsamością formalną i odrębnością semantyczną,' 32 , np. bal 'zabawa' i 'pień', fryzjerka 'kobieta fryzjer' i 'zawód fryzjera', narciarka 'kobieta narciarz' i 'czap-

\footnotetext{
30 Stownik terminów literackich, red. J. Sławiński, Wrocław 1976.

31 Lamańce językowe. Kalendarz — rok 2016, red. B. Pokrzywa, Warszawa 2015.

32 M. Majewska, Homonimia i homonimy w opisie językoznawczym, Warszawa 2002.
} 
ka narciarska', pani Walewska 'postać historyczna' i 'nazwa kosmetyku', parów$k a$ 'kąpiel' i 'rodzaj wędliny', rząd 'szereg' i 'władza w państwie'.

W zabawach z uczniami można rozszerzyć zakres wyrazów, które jednakowo brzmią, a różnią się tym razem pisownią, np. Chetm - hetm, karze - każe, kod - kot, lud - lód, marza - maża, pięć - piędź, pod róża - podróża, Pomorze pomoże, szef - szew, wiesz - kilka wież. Wzmacnianie ortografii zawsze bywa potrzebne, a wprowadzenie zabawowej atmosfery pozwoli zapewne uczniom rozszerzyć swoją dociekliwość i zapamiętywanie.

\section{Rymowanki i riposty w rozmowach codziennych}

Lingwiści badający język dzieci i młodzieży podkreślają odrębności w ich mówieniu, szczególnie w potocznym, codziennym ,gadaniu”. Zwracają uwagę na swego rodzaju poczucie humoru i dowcipną twórczość uczniów, która znajduje utrwalenie w rymowaniu ${ }^{33}$.

Maria Nagajowa zebrała ponad tysiąc takich jednostek, którymi ocenia się człowieka, rozmawia się z kimś, oddziałuje na wolę i uczucia, ocenia i komentuje codzienność. Znajdujemy tu wyrazy-onomatopeje: ecie-pecie, gadu-gadu, klituś -bajduś, koszatki-opałki, krętu-wętu, tere-fere, trala-lala, trele-morele oraz wiele mówionych, ale jakby mimo woli, z pomijaniem ich rozśmieszającej funkcji. Okazuje się, że bawi nas rymowanie, niezależnie od wieku, np. powitania i pożegnania - Cześć! Cześć! Całusów sto sześć!; Czołem! Społem!; Czuwaj! Kluski wsuwaj!; Dobranoc! Pchly na noc!; Serwus, jestem nerwus; Witam, o zdrowie pytam. Czasem tworzone przezwiska ${ }^{34}$ rozśmieszają słuchaczy: Babcia drypcia, Elka-pętelka, Ewka marchewka, Jacek-placek, Jurek, ogórek, kietbasa i sznurek, Skarżypyta bez kopyta, język lata jak łopata, Wojtek bez portek, Zosia Samosia. Umiejętność użycia dowcipnej odpowiedzi w rozmowie zawsze wysoko cenimy, gdyż ujęcie zagadnienia pół żartem, pół serio pozwala uniknąć dokuczenia komuś i doprowadzenia na przykład do krzykliwej awantury.

Podobne wypowiedzi tworzy i używa ich młodzież. J. Kowalikowa ${ }^{35}$ zwró- $^{2}$ ciła uwagę na twórczość ludyczną uczniów: autoparodię, neologizmy tworzone przedrostkami i przyrostkami (np. przerekin, przyćwir, przygłup, kujonita, zebraństwo), wprowadzanie imiesłowów biernych, rodzaju żeńskiego w miejsce męskiego, skracanie lub wydłużanie imion i nazwisk, zmiany w zwrotach fra-

${ }^{33}$ K. Pisarkowa, Wyliczanki polskie, Wrocław 1988; M. Nagajowa, Stownik rymowanek potocznego języka polskiego, Warszawa 2005.

${ }^{34}$ S. Kania, Z badań nad stownictwem i frazeologia gwary uczniowskiej, [w:] Z teorii i praktyki dydaktycznej języka polskiego, red. J. Kram, E. Polański, Katowice 1984, s. 159-160; K. Bakuła, Kto się przezywa, „Polonistyka” 1996, nr 10; M. Nagajowa, op. cit., s. 84-86.

35 J. Kowalikowa, Sygnały i nośniki humoru w języku mówionym uczniów krakowskich, [w:] Zagadnienia komunikacji dzieci i młodzieży, red. J. Porayski-Pomsta, Warszawa 1991, s. 93-100. 
zeologicznych (np. ciemny jak ta babka w rogu, kopnat go zaszczyt), zabawne porównania (np. durny jak margaryna mleczna, gęba jak Brama Floriańska).

Analiza zebranego materiału dostarcza dowodów na to, iż młodych krakowian cechuje twórczy, pełen inwencji stosunek do języka, co przejawia się we wszystkich jego warstwach: brzmieniowej, morfologicznej, leksykalnej, syntaktycznej. [...] Funkcja ludyczna stanowi szczególny rodzaj funkcji nie tylko ekspresywnej, ale i wolicjonalnej. Humor pozwala uczniom dystansować się wobec świata, obcego i straszącego różnymi zagrożeniami. [...] Efekty humorystyczno-komiczne wypowiedzi wynikają ze współdziałania trzech składników: językowego, sytuacyjnego oraz kulturowego ${ }^{36}$.

Wypada dodać, że w Stowniku rymowanek mamy sporo „brzydkich” wyrazów, gdyż obecnie popularne gadanie zachęca do bycia ordynarnym, stąd rozpowszechnienie się wulgaryzmów (pomijam ich reklamę). Mówią je dzieci, młodzież i raczej mężczyźni, nie tylko pijacy, obiboki i prostacy, lecz także wykształceni, zajmujący wysokie urzędowe stanowiska. Po prostu mamy modę na wulgarne mówienie!

\section{Dowcipne tytuły, podtytuły, zagadki}

Przedstawione tu sposoby rozśmieszania wyrazami nazywającymi dźwięki dotyczą także tytułów w cenionych tygodnikach. Jako przykład posłużą nam artykuły z „Polityki” ${ }^{77}$, w których na trzeciej stronie mamy ich zestaw, a wewnątrz otrzymujemy nowe, śmieszne lub zagadkowe podtytuły. Dziennikarze rozśmieszają nas wykrzyknieniami i wykrzyknikami, pisząc: rymowanki: Gary-mary (nr 31 'temat: gastronomia'), Prawo na łapu-capu (32), Angela wańka-wstańka (32), Od taktu do kompaktu (34), Ach, jaki dach (41); homonimy: Podróże w rurze (32 'wynalazki'), Kto rzadzi w rządzie (33), Zażarci w żarciu (33), Wojna Zachodu z Zachodem (33), Sztuka (bez) mięsa (41 'weganie'); antonimy: Filmy tak złe, że aż dobre (32), Glupie kroki madrych ludzi (32); zwroty frazeologiczne, przysłowia: Kwiatek do kożuszka (32), Złe lepszego poczatki (40), Niepogoda dla bogaczy (40), Być, by mieć (41), Jak haruje sie fach (41); zabawy wyrazami: Za pasze nasze $i$ wasze (31 'rośliny GMO'), Ceny na geny (31 'usługi genetyczne'), Szumienie narodu (32), Neurorewelacje i nerwościemy (33), Franciszek $z$ ducha franciszkański (33), Podrabiany rabin (40 'oszust'), Wiktoria Wiktora (40), Romantycy prawicy (40), Rom w dom (41 'Romowie'), Supermultiwicepremier (41). Jesteśmy zaskoczeni i rozśmieszeni różnorodnością tytułów i podtytułów opisujących dowcipnie dzisiejsze wydarzenia i problemy.

Oczywiście nie tylko tytuły stały się rozśmieszającymi wypowiedziami, dowcipy wprowadza się także w inne dziedziny życia. Sięga po nie sport ${ }^{38}$, re-

36 Ibidem, s. 94-95.

37 „Polityka” (tygodnik) 2016, nr. 31-41; W. Pisarek, Poznać prasę po nagłówkach, Kraków 1967.

${ }^{38}$ P. Nowak, Kultura śmiechu w XXI wieku - sport i dziennikarstwo sportowe okiem satyryków radiowych, [w:] Człowiek i kultura w komunikacji medialnej, red. M. Karwatowska, R. Litwiński, A. Siwiec, Lublin 2015, s. 175-190. 
klama $^{39}$, jak się spodziewamy, zachęcając do kupna towaru, np. Nie kupuj kota w worku! Czytaj reklamy! Nie wyważaj otwartych drzwi! Ten sam frazeologizm reklamuje kupno trzech towarów: Podróże twoich marzeń! Dach Twoich marzeń! Bielizna Twoich marzen!! Dostrzegamy skuteczność przekonywania znanych frazeologizmów w reklamach sprzedaży.

Zaskakują nas nowości obyczajowe, na przykład w toastach. Wyodrębnia się dowcipy powstałe przez powtórzenia, wprowadzenie wulgaryzmów, neologizmów, deminutywów ${ }^{40}$. Oto kilka przykładów: Zdrowie mamy, bo jak mamy, to pijemy! Chcesz być piękny i być młody, wypij piwo dla pogody! Pijmy, bo szkło się męczy! Cukier krzepi, wódka lepiej! Zdrowie pięknych pań i szybkich samochodów! Jeszcze po kropelce, póki wódka jest w butelce! Czas życia krótki, kropnijmy wódki! Cytaty nie wyczerpują różnorodności przykładów, a potwierdzają naszą chęć bawienia się słowami.

\section{Humor zeszytów szkolnych i wypowiedzi nauczycielskich}

Okazuje się, że uczniowie chętnie żartują w rozmowach, ale także popełniają błędy nieświadomie, stąd powstało powiedzenie „humor zeszytów szkolnych” ${ }^{1}$. Cytujemy kilka tego rodzaju przykładów z Kalendarza, w których dowcip to wynik nierozumienia przez uczniów wyrazów o odgłosach i dźwiękach:

Danuśka weszła na ławę i zaczęła grać na lutownicy; Janko gratby nawet na organkach, gdyby tylko miat smyczek; Krzyżak i jego koń stanąt na wzgórzu i zarżat uroczyście; Wojski przyłożyt ucho do ziemi i ustyszat tupot niedźwiedzich kopyt; Za ściana dat się styszeć tętent koni i po chwili do karczmy wpadta Danuśka z księżna mazowiecka.

Jak widzimy, nie wszyscy uczniowie rozumieją poszczególne wyrazy, zwroty, uwzględniają następstwo czasu itp. Pamiętamy: konieczna jest korekta tego, co się pisze, gdyż szybciej myślimy, niż piszemy, stąd między innymi nieoczekiwane dowcipy tekstowe.

W trudniejszej sytuacji są oceniani (hospitowani) nauczyciele, którzy nie zawsze zdają sobie sprawę, że popełniają błędy w czasie prezentowanej lekcji lub na kartach napisanego tekstu. Językoznawca zauważa w testach nauczycielskich pisanie nie na temat, pomijanie słów obowiązkowych w tekście (tak zwane słowa-klucze), pomijanie metatekstu, czyli informacji o porządku swego pisania,

${ }^{39}$ A.M. Lewicki, Wszystko na sprzedaż. Frazeologizmy jako tworzywo sloganów reklamowych, [w:] Problemy frazeologii europejskiej, red. A.M. Lewicki, Warszawa 1999, s. 69-80.

${ }^{40}$ E. Grabiec-Stasiewicz, Mechanizmy językowe stużące osiaganiu komizmu (na podstawie współczesnych toastów), [w:] Humor w perspektywie kulturowo-językowej, s. 217-225.

${ }^{41}$ A. Wójtowicz, Humor z zeszytów szkolnych: dziwne kategoryzacje i naiwny obraz świata, „Językoznawstwo” 2003, z. 3, s. 31-38; P. Mucha, Niezamierzony komizm stowny w dyskursie lekcyjnym, [w:] Humor w perspektywie kulturowo-językowej, s. 205-216. 
traktowanie tekstu jako całości i to nawet bez stereotypowych części, jak wstęp, rozwinięcie i zakończenie.

Sprawność komunikacyjna autorów analizowanych prac (a należy pamiętać, że są nimi czynni nauczyciele, w tym także ci, którzy uczą języka polskiego) jest bardzo ograniczona. Mają oni znaczne trudności w pisaniu na temat i znaczne trudności z utrzymaniem się w określonym gatunku mowy ${ }^{42}$.

Trudno wymagać sprawności pisania od uczniów, jeśli uczą źle przygotowani do zawodu nauczyciele (wiadomo, że nie wszyscy).

Naszą wiedzę o wypowiedziach nauczających czerpiemy też z badań o nadmiernej ekspresywności nauczycieli. Ekspresja to interesujące nas na przykład wykrzyknienia, którymi czasem zachęca się do nauki (np. Brawo, maleństwa! Jakie pracowite mróweczki!), a częściej mamy tu nerwowość nauczyciela. Niestety, zanotowano wypowiedzi, którym daleko do dowcipu ${ }^{43}$, mimo że zaskakują nowością, jak neologizmy-przezwiska: cherlak, ciapcia jedyna, durnie skończone, falsyfikaty niedouczone, gaduly wstrętne, glista mamucia, grzdyl, kupa tlumoków, ofiara losu, pieronie jeden, sklerotyk. Zanotowano też równoważniki, w których przeważa złośliwa ironia (np. Co za inteligencja! Co za geniusz! Co za odkrycie!) oraz krytyka, nagana, obelga (np. Co lekcje pytam o to samo! Skończone durnie! Gtupki! Idioci!; A wy nic nie rozumiecie, nic nie kojarzycie! Czy wam ktoś mózg wyprat? Co ty tam miauczysz?).

W mojej ocenie nauczyciele komunikujący się z uczniami takimi „dowcipami" to tyrani, którzy stanowczo powinni zrezygnować z pracy z dziećmi. Należą do tych, którzy sądzą, jak w szkołach przed wiekami, że uczniów należycie wychowuje tresura, rozkaz, obelga i poniżanie, gdy tymczasem najefektywniej wspólne osiąganie sukcesów czyni z nas życzliwych i uczynnych ludzi.

Obserwacja lekcji pozwala na zauważenie także wielu innych potknięć w mowie uczniów i nauczycieli, które wywołują uśmiech lub „śmiech całą gębą”, a wynikają między innymi z naruszenia systemu języka polskiego. Znajdujemy tak zwane przejęzyczenia i modyfikacje wyrazów (np. ściskoszczęk, militry, fatszat), przekręcanie członów (np. Jorze Mońskie, dziadał gad do obrazu), wprowadzenie pleonazmów (np. czarny Murzyn, zabić się na śmierć), dysharmonię stylistyczną (np. nasz ziomek Mickiewicz, wypasiony wieszcz ${ }^{44}$. Nie brakuje też w wypowiedziach wulgaryzmów, które stały się nie tylko powszechne w koleżeńskich rozmowach męskich, lecz także kobiety (dziewczyny) wzmacniają wyrazem niecenzuralnym ‘dowcipnym' swoją moc i siłę, a może nieuświadomioną modę.

42 J. Porayski-Pomsta, O sprawności językowej nauczycieli, „Studia Pragmalingwistyczne” 1997, s. 106-116.

43 O. Przybyla, Akty mowy o funkcji ekspresywnej w języku nauczycieli, [w:] Język w komunikacji, t. 3, red. G. Habrajska, Łódź 2001, s. 186-195.

${ }^{44}$ B. Jarosz, Humor w szkole, czyli o błędach językowych uczniów i nauczycieli, [w:] Humor w perspektywie kulturowo-językowej, s. 193-203. 


\section{Zabawy wyrazami dźwięku u poetów}

Wspominałam, że nazwy dźwięków i ruchu znajdujemy w staropolskich wierszach, zrytmizowanych dowcipnie w naszym języku. Dorzucimy kilka przykładów z późniejszych wieków.

Adam Mickiewicz (1798-1855), opisując przestrzeń, lepiej widział kolory, a pisząc o dźwiękach, lubił korzystać z porównań, np. Jankiel ... siekt struny jak deszczem nawalnym, tak lekkiemi ruchy; Jak gdyby zadzwoniło w strunę skrzydto muchy, Buchną dźwięk, jakby cała janczarska kapela ozwała się z dzwonkami, $z$ zelami, z bęben $\mathrm{i}^{45}$. Jako przykładowe teksty nauczyciele mogą analizować Koncert Jankiela i Polonez. Niemniej wysoko oceniam słowne nazwy tego, co słychać, analizując wiersze opisujące na przykład pola i łąki (ks. II), sad w Soplicowie (ks. II), gatunki much (ks. II), ptactwo domowe w ogrodzie (ks. III), gatunki grzybów w lesie (ks. III), litewskie lasy (ks. III), chmury na niebie (ks. III), dźwięk dzwonu wzywający na obiad (ks. III).

Także kilku współczesnych poetów, obdarzonych wyostrzonym słuchem, zachwyca nas swoimi wierszami. Julian Tuwim ${ }^{46}$ (1894-1953) ułożył znaną powszechnie Lokomotywę, Dwa wiatry oraz wiele innych, w tym Mróz:

W ostry mróz chłopek wiózł

$\mathrm{Z}$ lasu chrust na wozie,

Skrzypi coś, oś nie oś,

Trzaska chrust na mrozie.

Tężał mróz, wicher rósł,

Pędząc jak w sto koni,

Trzeszczy wóz, trzeszczy mróz,

Chłop zębami dzwoni.

Szkapa: brrr! Chłop jej: prr! -

A podwozie zgrzyta,

Gwiżdże wiatr, śwista bat,

Stukają kopyta!

Chrzęst i brzęk, zgrzyt i stęk,

Hałas jak w fabryce!

Mniejszy mróz, lżejszy wóz

Przy takiej muzyce.

Wiersze o dźwiękach ułożył też Jan Twardowski ${ }^{47}$ (1915-1995), np. Klasówka z religii. W utworze można się doszukać korzystania ze znanego nam słownika G. Knapiusza:

Temat: Modlitwa głuchego, który otrzymał słuch.

Dziękuję Ci, że już otrzymałem słuch, bo już słyszę:

brzęk,

łoskot

\footnotetext{
45 A. Mickiewicz, Pan Tadeusz, oprac. B. Włodarczyk, Kraków b.d.

46 J. Tuwim, Wiersze zebrane, oprac. A. Kowalczykowa, t. 1, 2, Warszawa 1975.

47 J. Twardowski, Klasówka z religii, www.nasze-wzruszenia.bloog.pl [dostęp: 12.10.2016].
} 


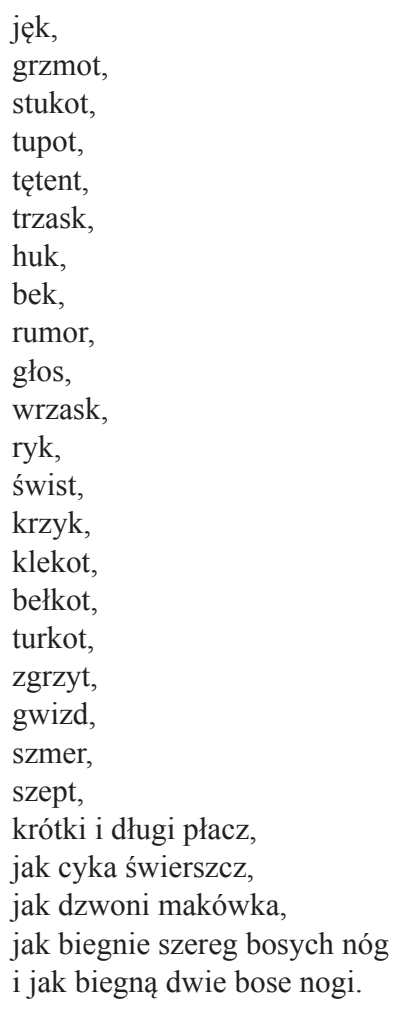

\section{Krótkie uwagi końcowe}

Problem uczenia i tworzenia dowcipów w szkole okazał się wielu badaczom znany i leżący na sercu (zob. Bibliografia). Wydaje nam się, że łatwiej żyje się ludziom o pogodnym widzeniu rzeczywistości, dlatego staramy się, by uczniowie umieli tak mówić, by można się było bodaj trochę pośmiać, ale także, by wiedzieli, z jakiej leksyki i frazeologii korzystać, tworząc dowcipy. Okazało się, że warto mieć wiedzę przede wszystkim o wyrazach dźwiękonaśladowczych, ale także o homonimach, rymowankach, wyliczankach, neologizmach, frazeologizmach itp. Mając te informacje, można wykorzystywać głoski, dźwięki, wyrazy, wyrażenia, zwroty do tworzenia śmiesznych rymowanek, opinii, ripost, podtytułów, sprawozdań sportowych, a nawet okolicznościowych toastów i życzeń.

Okazuje się, że moda na wesołość dotarła także do zakładanych i cenionych obecnie centrów nauki, co nas jeszcze bardziej zachęca do rozpowszechnienia zabaw wyrazami i frazeologizmami.

Może zatem to dobry moment, żeby przypomnieć sobie, że nauka połączona z zabawą personalizuje, zaciekawia i przyciąga mimowolnie, budując system dobrych skojarzeń, a przede wszystkim rozbudza naturalną ciekawość świata, za- 
miast ją usypiać uczeniem się ,„pod testy”. Nie znaczy to oczywiście, że zabawa ma zastąpić rzetelną pracę i wysiłek, chodzi o głęboką zmianę mentalności, społecznej świadomości, w których konwencja zabawy przyczynić się może także do przełamania kolejnych negatywnych skutków nowoczesności, czyli braku wspólnotowości i kryzysu intymności ${ }^{48}$.

\section{Źródła}

Biernat z Lublina, Ezop, wstęp i oprac. S. Grzeszczuk, J. Gruchała, Kraków 1997.

Knapiusz G., Thesaurus polono-latino-grecus, wyd. 2, Kraków 1643.

Krasicki I., Bajki i przypowieści, Warszawa 1779.

Lamańce językowe. Kalendarz — rok 2016, red. B. Pokrzywa, Warszawa 2015.

Mickiewicz A., Pan Tadeusz, oprac. B. Włodarczyk, Kraków b.d.

„Polityka” (tygodnik) 2016, nr 31-41.

Praktyczny słownik wspótczesnej polszczyzny, t. 1-50, red. H. Zgółkowa, Poznań 1994-2005.

Rej M., Figliki, Kraków 1562.

Tuwim J., Cztery wieki fraszki polskiej, Warszawa 1937.

Tuwim J., Wiersze zebrane, A. Kowalczykowa, t. 1, 2, Warszawa 1975.

Twardowski J., Klasówka z religii, www:nasze-wzruszenia.bloog.p1 [dostęp: 12.10.2016].

\section{Bibliografia}

Bakuła K., Kto się przezywa, „Polonistyka” 1996, nr 10.

Bąba S., Innowacje frazeologiczne wspótczesnej polszczyzny, Poznań 1989.

Bąk P., Gramatyka języka polskiego, Warszawa 1977.

Boniecka B., Funkcje składniowe wyrazów onomatopeicznych, „Polonika” 1977, z. 3.

Bralczyk J., Aaa, kotki dwa, szare, bure obydwa, [w:] Język polski. Arkusze maturalne, red. M. Magenta-Siemiaszko, Warszawa 2016.

Buttler D., Polski dowcip językowy, Warszawa 1996.

Gawdzik W., Gramatyka na wesoło, Warszawa 1970.

Gawdzik W., Ortografia na wesoło, Warszawa 1971.

Grabiec-Stasiewicz E., Mechanizmy językowe stużace osiaganiu komizmu (na podstawie wspótczesnych toastów), [w:] Humor w perspektywie kulturowo-językowej, red. M. Karwatowska, L. Tymiakin, Lublin 2013.

Gry i zabawy w kształceniu językowym, red. H. Wiśniewska, Lublin 2000.

Humor w perspektywie kulturowo-językowej, red. M. Karwatowska, L. Tymiakin, Lublin 2013.

Jarosz B., Humor w szkole, czyli o błędach językowych uczniów i nauczycieli, [w:] Humor w perspektywie kulturowo-językowej, red. M. Karwatowska, L. Tymiakin, Lublin 2013.

Jędrychowska M., Poza nudą. O zabawach, grach i rozrywkach, „Ojczyzna-Polszczyzna” 1992.

Jodłowski S., Podstawy polskiej składni, Warszawa 1976.

Jodłowski S., Polskie czasowniki niefleksyjne, [w:] W stużbie nauce i szkole, red. M. Szymczak, Warszawa 1970.

${ }^{48}$ M. Piechota, Centrum nauki - nowy model komunikacji edukacyjnej, [w:] Komunikacja. Tradycja i innowacje, red. M. Karwatowska, A. Siwiec, Chełm 2013, s. 546. 
Kania S., Z badań nad stownictwem i frazeologia gwary uczniowskiej, [w:] Z teorii i praktyki dydaktycznej języka polskiego, red. J. Kram, E. Polański, Katowice 1984.

Klemensiewicz Z., Składnia, stylistyka, pedagogika językowa, red. A. Kałkowska, Warszawa 1982.

Kowalikowa J., Sygnały i nośniki humoru w języku mówionym uczniów krakowskich, [w:] Zagadnienia komunikacji dzieci i młodzieży, red. J. Porayski-Pomsta, Warszawa 1991.

Laskowski R., Podstawowe pojęcia morfologii, [w:] Gramatyka wspótczesna języka polskiego, red. R. Grzegorczykowa, R. Laskowski, H. Wróbel, Warszawa 1984.

Laskowski R., Wykrzykniki - czasowniki wykrzyknikowe, [w:] Encyklopedia języka polskiego, red. S. Urbańczyk, M. Kucała, Wrocław 1999.

Lewicki A.M., Wszystko na sprzedaż. Frazeologizmy jako tworzywo sloganów reklamowych, [w:] Problemy frazeologii europejskiej, red. A.M. Lewicki, Warszawa 1999.

Majewska M., Homonimia i homonimy w opisie językoznawczym, Warszawa 2002.

Mączyński M., O czasownikach onomatopeicznych oznaczających mówienie, „Język Polski” 1984, z. $1-2$.

Mikołajczak A., Rozumienie znaczenia wybranych związków frazeologicznych $w$ testach egzaminacyjnych na polonistyke, „Studia Pragmalingwistyczne” 1977.

Mucha P., Niezamierzony komizm stowny $w$ dyskursie lekcyjnym, [w:] Humor w perspektywie kulturowo-językowej, red. M. Karwatowska, L. Tymiakin, Lublin 2013.

Nagajowa M., Stownik rymowanek potocznego języka polskiego, Warszawa 2005.

Nowak P., Kultura śmiechu w XXI wieku - sport i dziennikarstwo sportowe okiem satyryków radiowych, [w:] Człowiek i kultura w komunikacji medialnej, red. M. Karwatowska, R. Litwiński, A. Siwiec, Lublin 2015.

Pajdzińska A., Studia frazeologiczne, Łask 2006.

Pawłowska R., Praca nad znaczeniem wyrazu na lekcjach języka polskiego, „Kształcenie Językowe w Szkole" 10, 1998.

Piechota M., Centrum nauki - nowy model komunikacji edukacyjnej, [w:] Komunikacja. Tradycja i innowacje, red. M. Karwatowska, A. Siwiec, Chełm 2013.

Pisarek W., Poznać prasę po nagłówkach, Kraków 1967.

Pisarkowa K., Wyliczanki polskie, Wrocław 1988.

Porayski-Pomsta J., O sprawności językowej nauczycieli. Na podstawie analizy początków i zakończeń wypracowań, „Studia Pragmalingwistyczne” 1997.

Problemy frazeologii europejskiej, red. A.M. Lewicki, Warszawa 1999.

Przybyla O., Akty mowy o funkcji ekspresywnej w języku nauczycieli, [w:] Język w komunikacji, red. G. Habrajska, t. 3, Łódź 2001.

Puzynina J., O metodzie leksykograficznej w „, Thesaurusie” Knapskiego, „Poradnik Językowy” 1956.

Rospond S., Gramatyka historyczna języka polskiego, Warszawa 1971.

Słownik terminów literackich, red. J. Sławiński, Wrocław 1976.

Stałość i zmienność związków frazeologicznych, red. A.M. Lewicki, Lublin 1982.

Synowiec H., Problemy frazeologii w kształceniu językowym uczniów, [w:] Wiedza o języku i kompetencje językowe uczniów, red. B. Niesporek-Szamburska, Katowice 2012.

Wiśniewska H., Nauczanie dowcipu w szkole, [w:] Humor i karnawalizacja we współczesnej komunikacji językowej, red. J. Mazur, M. Rumińska, Lublin 2007.

Wiśniewska H., Zasobność stownika ,verba dicendi" w bajkach Biernata z Lublina, [w:] W kreggu dawnej polszczyzny, red. M. Mączyński, E. Horyń, E. Żmuda, Kraków 2016.

Wójtowicz A., Humor z zeszytów szkolnych: dziwne kategoryzacje i naiwny obraz świata „Językoznawstwo. Nauki Filologiczne" 2003, nr 3. 